\title{
SPECIFICITY, DEFINITENESS, AND L2 ARTICLE PRODUCTION IN THE L1 SERBIAN/L2 ENGLISH LINGUISTIC ENVIRONMENT ${ }^{1}$
}

\section{Марта Величковић*}

Since little research exists on English L2 article production in the Serbian linguistic environment, the goal of this descriptive study was to identify anytrends in L2 article production, as they pertain to definiteness and specificity (following Ionin et al., 2004). In order to measure this production, four contexts were defined based on the following two semantic features: [ \pm specific] and [ \pm definite]. Considering that Serbian is a language with no article system, and a language that codes specificity (Trenkic 2002, 2004), unlikeEnglish which codes definiteness, combinations of these features should indicate particular contexts that may not only identify any possible patterns in the L2 article production of this segment of the population, but also prove useful as a foundation for further research, and the study of the effects that information of this kind could have on L2 instruction. Based on the findings of previous research, most article substitution and article omission errors are expected in the [+definite, -specific] and [-definite, +specific] contexts. The current results indicated that the sample of participants has a strong tendency of overusing the definite article with indefinites, and to a lesser extent the indefinite article with definites. Furthermore, some unexpected fluctuations were noted in the [+definite +specific] and [definite -specific] contexts, indicating that the participants have not yet consistently adopted either the category definiteness or specificity.

1 Prepared as a part of the project Modern Trends in Researching English Linguistics and Anglophone Literature and Culture, conducted at the University of Niš Faculty of Philosophy (No. 183/1-16-1-01).

An earlier version of this paper was presented at the conference Language, Linguistics, Context held in April 2019 at the Faculty of Philosophy, University of Nis.

* Департман за англистику, Филозофски факултет, Универзитет у Нишу 
Key words: specificity, definiteness, the article system of the English language, L1 Serbian.

\section{INTRODUCTION}

L2 article production is a topic that has not received much attention in the Serbian linguistic environment (a noteworthy exception is the work done by Trenkic, 2002; 2004; 2007; 2009). Yet, due to both article omission and article substitution, which persist to higher levels of proficiency among the L1 Serbian/L2 English population, their L2 article production is a topic that warrants further study. One of the idiosyncrasies regarding the grammatical category of the article system is that it is not to be found in all the languages of the world. One such language is Serbian, which relies on a system of adjectives, demonstrative pronouns, numerals, etc., to establish the appropriate referential relations. ${ }^{2}$ Another of its idiosyncrasies is that irrespective of whether or not a particular language does have a system of articles, its linguistic unitscan code either specificity or definiteness. So not only does it not have a grammatical category of articles, but Serbian is also said to code specificity. On the other hand,the English language not only contains a three-article grammatical category, but it also codes definiteness. Thus, there are some concerns about the Serbian L2-learners' ability to acquire the semantic feature that is not present in their L1, which could account for the recurring article omission and article substitution. The possibility of isolating and combining the [ \pm specific] and the [ \pm definite] feature provides us with a suitable framework for the systematic analysis of the L2 article production of the target population. The identification of problem areas for this population may have a positive effect on the specific type of instruction designed for it, resulting in an improvement in L2 article production.

\section{THEORETICAL BACKGROUND}

The theoretical framework for the current study was outlined by Ionin (2003a; 2003b; 2003c; 2004; 2008a; 2008b; Ionin \& Montrul 2009), and is based on specificity and definiteness as they pertain to languages with and without

2 For a more detailed side-by-side comparison of the English article system and the proposed counterparts in the Serbian language see Djordjevic (1989). 
articles.The relationship between the two categories is a complex one. A working definition of specificity in this framework is thatit is a discourserelated category related to the knowledge or the mind state only of the speaker. This accountis based on Fodor and Sag's (1982) view of specificity,which includes 'speaker intent to refer', in addition tothe mere existential presuppositionthat was originally the predominant feature of specificity. In other words, if a determiner phrase (DP) has the feature [+specific], then the speaker intends to refer to a unique entity in the set denoted by the noun phrase (NP), it the sense that $\mathrm{s} /$ he considers this entity to possess some noteworthy property relevant to the ongoing discourse.

Although definiteness is also a discourse-related category, its defining feature is that it reflects the state of knowledge of both the speaker and the hearer. Thus, if a (DP) has the feature [+definite], then both the speaker and hearer presuppose the existence of a unique entity in the set denoted by the NP.

In the English language, the definite article the and the indefinite articlea, are used in [+definite] and [-definite] contexts, respectively. Specificity does not play a role in the English language article system, with the exception that some authors consider the possibility of there being a colloquial marker of specificity in English, the demonstrative determiner this, but only in indefinite contexts. The following illustrative examples were taken from Lyons (1999:176, ex. 51):

a. Peter intends to marry a/this merchant banker - even though he doesn't get on at all with her.

b. Peter intends to marry a/?? this merchant banker - though he hasn't met one yet.

In addition to the differences that exist between specificity and definiteness, is not always the case that the [+definite] feature will necessarily require the use of the definite article each time. In the following examplestaken from Ionin et al. (2004: 10), it is clear that the use of the is warranted despite the fact that the aforementioned feature cannot be ascribed to either of the referents in question. It would seem that the noteworthiness that is associated with specificity in this instancewarrants the use of the. The authors indicate that this is an example of the attributive/referential use of the definite article, respectively, as described by Donnellan (1966):

a. I'd like to talk to the winner of today's race - she is my best friend! 
b. I'd like to talk to the winner of today's race - whoever that is; I'm writing a story about this race for the newspaper.

In example a, the 'noteworthiness' condition is satisfied by the additional feature ascribed to the referent in question, leading the authors to conclude that specificity is independent of definiteness.

The basis of Ionin's theoretical account of L2 article production in light of specificity and definiteness is her proposed theory on the Article Choice Parameter and the Fluctuation Hypothesis (2003a; 2004). The Article Choice Parameter is said to have two settings, definiteness and specificity, and only one of these settings is selected based on the speaker's L1. The author further indicates that this is rendered possible due to the fact that all learners have complete access to Universal Grammar, and thus to both settings for the Article Choice Parameter. During the process of L2 article acquisition, if the settings of the NNSs' L1 and L2 do not coincide, fluctuation is evident in their L2 production, where the same articlecan be used in both definite and indefinite contexts. A case in point would be the following two items taken from the questionnaire developed by Ionin et al. (2004: 42), where the indefinite article was used excessively instead of the definite one:

(28) [+definite, +specific]

\section{Meeting in a park}

Andrew: Hi, Nora. What are you doing here in Chicago? Are you here for work?

Nora: No, for family reasons. I am visiting (the, a, --) father of my fiancé he is really nice, and he is paying for our wedding!

(29) [+definite, -specific]

\section{Phone conversation}

Mathilda: $\mathrm{Hi}$, Sam. Is your roommate Lewis there?

Sam: No, he went to San Francisco for this week-end.

Mathilda: I see. I really need to talk to him - how can I reach him in San Francisco?

Sam: I don't know. He is staying with (a, the, --) mother of his best friend I'm afraid I don't know who she is, and I don't have her phone number. 
Examples of the overuse of the definite article with indefinites are illustrated in the following examples, taken from the same source (ibid, 49):

(32) a. [-definite, +specific]

I am visiting (a, the, --) friend from college - his name is Sam Bolton, and he lives in Cambridge now.

b. [-definite, -specific]

He is staying with (a, the, --) friend - but I have no idea who that is.

Until the settings of the parameters are reset so that they accurately reflect the settings of the targeted L2, the NNSs will fluctuate between definiteness and specificity. When there is a direct overlap between the settings of their L1 and L2, the chance of errors occurring decreases.

In her work, Ionin et al. (ibid) focused on NNSs whose L1 did contain the category of articles (primarily speakers of Spanish or Korean), with the expectation that they would transfer the category coded in their L1 into their L2 article production. In the case of NNSs whose L1 did not contain the category of articles (such as Russian), the author wanted to determine which parameter setting they would opt for in their L2 article production, and if they would do so consistently, i.e. whether their L2 would show signs of fluctuation. The results indicated that the participants whose L1 did contain a category of articles showed signs of more accurate L2 article production, but one segment of this population showed behavior that was similar to that of the participants whose L1 did not contain the category of articles. To further analyze this issue, Ionin et al. (ibid) were motivated to use the two semantic features, [ \pm specific] and [ \pm definite], to investigate L2 article production in specially designed contexts. This provided a suitable framework for the systematic study of L2 article production. Certaintrends in L2 article production were expected, such as using the with specific definites, and $a$ with non-specific indefinites, to mimic native-like proficiency. Furthermore, contexts predicted to be most challenging for the studied groups of NNSshad the following combination of features: [+definite, -specific] and [-definite, +specific].

Ionin et al. (ibid) noted that participants whose L1 had no category of articles (Russian) and those whose L2 did (Korean) overused the in contexts marked by the feature [+specific] more than with [-specific], and overused $a$ more in contexts marked by the [-specific] feature than with [+specific]. At the same time correct use of thewas noted in the [+definite, +specific] context. 
This information is presented in table form (Table 1).

Table 1. An overview of the four contexts and the expected article production

\begin{tabular}{lcc}
\hline & +definite (target $t h e)$ & -definite (target $a$ ) \\
\cline { 2 - 3 } +specific & Correct use of the & Overuse of the \\
-specific & Overuse of $a$ & Correct use of $a$ \\
\hline
\end{tabular}

Source: Ionin et al., 2004

Based on the aforementioned, the aim of the current study is to determine the L2 article production of a group of L1 Serbian/L2 English learners at the tertiary level in the four contexts obtained by combining the features[ \pm specific] and $[ \pm$ definite]. The research question was defined as follows:

Will an overuse of the definite article be found for the [-definite, +specific] context, and the indefinite article for the [+definite, -specific] context, or in other words, will there be an overuse of the with indefinites and overuse of $a$ with definites?

\section{THE STUDY}

\section{The participants}

The sample of participants included university level students majoring in various subjects at the University of Nis. The total number of participants was $\mathrm{N}=89$, of whichN=31 were English language majors and $\mathrm{N}=58$ were nonEnglish language majors.

\section{The measuring instrument}

The participants were asked to complete a single questionnaire, as designed by Ionin, Ko \& Wexler (2004), in the form of a forced-choice elicitation task. The instrument consisted of 40 items specifically designed to accommodate the [ \pm specific] and [ \pm definite] features: $12[+$ specific +definite] items, $8[+$ specific definite] items, 8 [-specific +definite] items, and 12 [-specific -definite] items. 
Each item was presented in the form a dialogue, and there was one blank each which required the use of either the definite article, the indefinite article, or the zero article.

The participants completed the questionnaire during their regular tutorials with their respective instructors. All the data were coded as input for the SPSS program. In addition to coding the responses the participants provided for each item (correct, and type of incorrect response), four additional 'dimensions' were calculated to keep track of the participants' L2 article production: a[+specific +definite], [+specific -definite], [-specific +definite], and [-specific -definite] dimension, for each of which the percentage of (in)correct responses was calculated to determine the participants' performance on the L2 article production test.

\section{THE RESULTS}

Considering that the participants differedbased on their choice of study program, the results are first presented for the English language majors, and then for the non-English language majors, even though their results will be discussed as a group.

Table 2. The percentage of provided responses per dimension

\begin{tabular}{ccccccc}
\hline & \multicolumn{3}{c}{ +definite } & \multicolumn{3}{c}{-definite } \\
\cline { 2 - 7 } & \multirow{2}{*}{ Correct } & $\begin{array}{c}\text { Incorrect } \\
a\end{array}$ & $\begin{array}{c}\text { Incorrect } \\
\text { zero }\end{array}$ & Correct & $\begin{array}{c}\text { Incorrect } \\
\text { the }\end{array}$ & $\begin{array}{c}\text { Incorrect } \\
\text { zero }\end{array}$ \\
\cline { 2 - 7 } specific & $(\mathrm{n}=356)$ & $(\mathrm{n}=15)$ & $(\mathrm{n}=1)$ & $(\mathrm{n}=217)$ & $(\mathrm{n}=27)$ & $(\mathrm{n}=0)$ \\
& $95.7 \%$ & $4.0 \%$ & $0.3 \%$ & $87.9 \%$ & $10.9 \%$ & $0 \%$ \\
-specific & $(\mathrm{n}=233)$ & $(\mathrm{n}=12)$ & $(\mathrm{n}=3)$ & $(\mathrm{n}=392)$ & $(\mathrm{n}=5)$ & $(\mathrm{n}=0)$ \\
& $94 \%$ & $4.8 \%$ & $1.2 \%$ & $98.7 \%$ & $1.3 \%$ & $0 \%$ \\
\hline
\end{tabular}

As seen from Table 2, for the dimension [+definite +specific], the overall percentage of correct responses (the definite article) is $95.7 \%$.The most frequently made mistake is the use of the indefinite article with definites, which accounts for $4 \%$ of all the responses. For the dimension [+definite specific], the correct response of the definite article was provided in $94 \%$ of all instances.The most frequently made mistake was the use of the indefinite article, $4.8 \%$ of the responses. For the dimension [-definite +specific], the 
correct response (the indefinite article) was provided $87.9 \%$ of the time, while the definite article was incorrectly used $10.9 \%$ of the time. And for the [definite -specific] dimension, the correct response of the indefinite article occurred in $97.2 \%$ of all instances, while the definite article was incorrectly used in $1.3 \%$ of the responses.

Table 3. The percentage of incorrect responses provided for each of the four dimensions

\begin{tabular}{ccccc}
\hline & \multicolumn{2}{c}{ +definite } & \multicolumn{2}{c}{-definite } \\
\cline { 2 - 5 } & Incorrect & Incorrect & Incorrect & Incorrect \\
& $a$ & zero & the & zero \\
\cline { 2 - 5 } +specific & $(\mathrm{n}=16)$ & $(\mathrm{n}=1)$ & $(\mathrm{n}=28)$ & $(\mathrm{n}=0)$ \\
& $22.5 \%$ & $1.4 \%$ & $39.4 \%$ & $0 \%$ \\
-specific & $(\mathrm{n}=12)$ & $(\mathrm{n}=3)$ & $(\mathrm{n}=11)$ & $(\mathrm{n}=0)$ \\
& $16.9 \%$ & $4.2 \%$ & $15.5 \%$ & $0 \%$ \\
\hline
\end{tabular}

Of all the incorrect responses provided, 39.4\%were overuse of thein the [definite +specific] dimension, and $22.5 \%$ were overuse of $a$ in the [+definite +specific] dimension. The two following highest percentages of incorrect responses were recorded in the [-definite -specific] dimension (overuse of the with $15.5 \%$ ), and in the [+definite -specific] dimension, $16.9 \%$ (overuse of $a$ ).

The remaining set of results are provided for the group of non-English language majors.

Table 4. The percentage of correct responses per dimension

\begin{tabular}{ccccccc}
\hline & \multicolumn{3}{c}{ +definite } & \multicolumn{3}{c}{-definite } \\
\cline { 2 - 7 } & Correct & $\begin{array}{c}\text { Incorrect } \\
a\end{array}$ & $\begin{array}{c}\text { Incorrect } \\
\text { zero }\end{array}$ & Correct & $\begin{array}{c}\text { Incorrect } \\
\text { the }\end{array}$ & $\begin{array}{c}\text { Incorrect } \\
\text { zero }\end{array}$ \\
\cline { 2 - 7 } +specific & $(\mathrm{n}=356)$ & $(\mathrm{n}=158)$ & $(\mathrm{n}=106)$ & $(\mathrm{n}=242)$ & $(\mathrm{n}=94)$ & $(\mathrm{n}=70)$ \\
& $57.4 \%$ & $25.48 \%$ & $17.1 \%$ & $59.6 \%$ & $23.15 \%$ & $17.24 \%$ \\
-specific & $(\mathrm{n}=247)$ & $(\mathrm{n}=83)$ & $(\mathrm{n}=101)$ & $(\mathrm{n}=466)$ & $(\mathrm{n}=138)$ & $(\mathrm{n}=86)$ \\
& $57.31 \%$ & $19.26 \%$ & $23.43 \%$ & $67.54 \%$ & $20 \%$ & $12.5 \%$ \\
\hline
\end{tabular}

Of all the responses provided in the [+definite +specific] dimension, $57.4 \%$ were correct (the definite article), while the indefinite article was incorrectly 
used in $25.48 \%$ of the responses. In the[+definite -specific] dimension, $57.31 \%$ of all the answers were correct (the definite article), the zero article was incorrectly used in $23.43 \%$ of the responses, and the indefinite article in $19.26 \%$. In the[-definite +specific] dimension, the correct response (the indefinite article) was provided in $59.6 \%$ of all instances, while the definite article was incorrectly used $23.15 \%$ of the time, and the zero article $17.24 \%$. And for the [definite -specific] dimension, the correct response of the indefinite article was used $67.54 \%$ of the time, followed by the incorrectly used definite article with $20 \%$, and the incorrectly used zero article with $12.5 \%$.

Table 5. The percentage of incorrect responses for each of the four dimensions

\begin{tabular}{ccccc}
\hline & \multicolumn{2}{c}{ +definite } & \multicolumn{2}{c}{-definite } \\
\cline { 2 - 5 } & Incorrect & Incorrect & Incorrect & Incorrect \\
& $a$ & zero & the & zero \\
\cline { 2 - 5 } tspecific & $(\mathrm{n}=158)$ & $(\mathrm{n}=106)$ & $(\mathrm{n}=99)$ & $(\mathrm{n}=70)$ \\
& $16.99 \%$ & $11.4 \%$ & $10.6 \%$ & $7.5 \%$ \\
-specific & $(\mathrm{n}=83)$ & $(\mathrm{n}=101)$ & $(\mathrm{n}=227)$ & $(\mathrm{n}=86)$ \\
& $8.92 \%$ & $10.86 \%$ & $24.44 \%$ & $9.24 \%$ \\
\hline
\end{tabular}

Of all the incorrect responses provided, $24.44 \%$ weremade up of the incorrect use of thein the [-definite -specific] dimension, followed by $16.99 \%$ of the use of ain the [+definite +specific] dimension, i.e. overuse of the definite article with indefinites and the indefinite article with definites, respectively. The two following highest percentages of incorrect responses were recorded for the zero article in the [+definite +specific] and [+definite -specific] dimension, with $11.4 \%$ and $10.86 \%$ respectively.

\section{DISCUSSION}

In accordance with the research question, the aim of the study was to determine whether the sample of L1 Serbian/L2 English speakers will overuse the with indefinites and overuse $a$ with definites.

In the case of the English language majors, overuse of the definite article was noted with indefinites (in the [-definite +specific] dimension), ata rate of almost $40 \%$. However, overuse of the indefinite article with definites in the [+definite -specific] dimension was noted to a much lesser extent, at 
approximately $5 \%$. Furthermore, overuse of the indefinite article, at a rate of one-fifth of the responses was noted in the [+definite +specific] dimension, which was not expected.

The trend of the results recorded for the non-English language majors was to an extent similar. Overuse of the definite article was noted with indefinites, but not in the [-definite +specific] dimension as was expected, but instead in the [-definite -specific] dimension. This overuse also comes at a lower rate than that of the English-language majors, with almost one-fourth of the responses. Overuse of the indefinite article with definites was also noted, once again not in the [+definite -specific] dimension as expected, but instead in the [+definite +specific] dimension, at a rate of less than one-fifth of the responses. The rate of incorrect responses for this segment of the L1 Serbian/L2 English population was not highest in the expected dimensions of [+definite -specific] and [definite +specific], where the rate of incorrect use of the zero article and of the definite article is roughly one-tenth of the responses, respectively.

Viewed merely along the lines of definiteness vs specificity, and our sample as a group, the research question can be said to have been answered in part in the affirmative, in the sense that the participants tended more toward over using the with indefinites (one half of the incorrect responses in the [-definite +specific] category, and $40 \%$ in the [-definite -specific] category) than toward using $a$ with definites (also roughly $40 \%$ in the [+definite +specific] category, and one-fourth of the responses in the [+definite -specific] category).Viewed on a more in-depth scale, the dimensions where the features of [ \pm specific] and [ \pm definite] did not align, the results did not conform to the initial expectations. This segment of the L1 Serbian/L2 English population performed unexpectedly poorly in the [+definite +specific] dimension, as in the [-definite -specific] dimension, with a high rate of errors of almost $40 \%$. If we were to refer back to the initial definitions provided for definiteness and specificity, uniqueness and noteworthiness, it was expected that if these two criteria were (not) met at the same time, the use of the correct article would beexpected.

However, these results indicate that the studied segment of the L1 Serbian/L2 English population are following what Ionin et al. (2004) refer to as the 'miscellaneous pattern' of article production, as opposed to a 'definiteness pattern' or 'specificity pattern'. They therefore offer evidence in favor of the Fluctuation Hypothesis, indicating a lack of consistency on the part of the participants in adhering to either specificity or definiteness in L2 article production.The excessive fluctuation could not be ascribed to mere L1 transfer, 
due to the aforementioned lack of consistency. If these NNSs in fact did not have access to Universal Grammar, they would be denied access to the semantic feature of definiteness and thus non-random errors could be expected (Ionin \& Montrul, 2009). The data compiled as part of this study seems to support the claim in favor of Universal Grammar.

Of the four studied dimensions, the one that this group of participants struggled with the most was the [-definite +specific] dimension, where they exhibited a high rate of overuse of the definite article (one half of the incorrect response). A possible explanation for the overuse of the with indefiniteswas proposed by Ko et al. (2007). They cited that in the English language, more often than not definite noun phrases can be found which can be described as more likely having the [+specific] rather than the [-specific] feature. This led to the conclusion that NNSs find it easier torespond to specificity, and do so better than to definiteness.Also, specificity, in comparison to definiteness, is possibly a more basic feature, that is, specificity appears tocrosscut definiteness. This could be relevant for the L1 Serbian/L2 English population. Frequency of occurrence as one of the key features of article production was also pointed out by Master (1997), who cited that the most frequently used article in the English language is precisely the zero article, and that one of the ensuing results is that NNSs come across it more frequently than they do the other articles, which results in their acquiring it first, and could account for perceived article omission. Thus, the linguistic environment itself could provethe deciding factor for setting the parameter value to specificity or definiteness, which could account for L2 article production in contexts where the L1 does not code definiteness (Ionin et al.2008b). They determined that NNSs should look for the so-called 'triggers' in the L2 which would help them correctly determine the meaning of the English articles, which are mostly discourse-based. What this group of learners need to determine is whether the definite article is used only as an indication of uniqueness from the viewpoint of both interlocutors, or whether it is an indicator of a particular feature which is considered relevant by the speaker. 


\section{CONCLUSION AND IMPLICATIONS FOR FURTHER STUDY}

Based on the aforementioned, we can conclude that even at the tertiary level of education, improvements in L2 article production are still required, due to the persistent article substitution errors recorded in this study. The implications for the L2 article instruction process are the following. Initially, the assumption may have been that only two of the categories needed to be specifically and systematically explained in the EFL/ESL classroom: the [+definite -specific] and the [-definite +specific]. At this point, it would seem unwise to reduce the L2 learners' exposure to only two of the four contexts. Examples of all four should be presented consistently, with clear explanations which would include reference to both uniqueness and noteworthiness.

Sincethis segment of the L1 Serbian/L2 English population was viewed as a whole in this study, further research should analyze the specific differences between the two subgroups of participants and check for any possible statistically significant differences between the two in terms of L2 article production, based on their performance in the four isolated dimensions. Furthermore, additional analyses should include other variables, such as perhaps age of exposure or length of exposure to the English language, as well as any possible correlation between the participants' levels of proficiency and L2 article production.

\section{REFERENCES}

Djordjevic, R. (1989). Engleski i srpskohrvatski jezik: kontrastivna gramatika imenicke grupe. Beograd: Naucna knjiga.

Donnellan, K. S. (1966). Reference and definite descriptions. Philosophical review 75, 281-304.

Fodor, J. \& Sag, I. (1982). Referential and Quantificational Indefinites. Linguistics and Philosophy 5, 355-398.

Ionin, T. \& Montrul, S. (2009). Article use and generic reference: parallels between L1and L2-acquisition. In Garcia-Mayo, M. \& Hawkins, R. (Eds.). Second language acquisition of articles: empirical findings and theoretical implications (pp 147-173). Amsterdam: John Benjamins.

Ionin, T. (2003a). Article semantics in second language acquisition. Ph.D. thesis. MIT. Distributed by MIT Working Papers in Linguistics. 
Ionin, T. (2008a). An experimental investigation of the semantics and pragmatics of specificity. In Abner, N. \& Bishop, J. (Eds.). Proceedings of the 27th West Coast Conference on Formal Linguistics (pp. 229-237). Somerville, MA: Cascadilla Proceedings Project.

Ionin, T., \& Wexler, K. (2003b). The certain uses of the in L2 English. In Liceras, J. M., Zobl, H. \& Goodluck, H. (Eds.). Proceedings of the $6^{\text {th }}$ Generative Approaches to Second Language Acquisition Conference (GASLA 2002) (pp. 150-160). Somerville, MA: Cascadilla Proceedings Project.

Ionin, T., Zubizarreta, M. L., \& Batista, S. (2008b). Sources of linguistic knowledge in the second language acquisition of English articles. Lingua118(4), 554-576.

Ionin. T., Ko, H. \& Wexler, K. (2003c). Specificity as a grammatical notion: evidence from L2-English article use. In Garding, G. \& Tsujimura, M. (Eds.). WCCFL 22 Proceedings (pp. 245-258). Somerville, MA: Cascadilla Press.

Ionin. T., Ko, H. \& Wexler, K. (2004). Article semantics in L2 acquisition: the role of specificity. Language Acquisition 12(1), 3-69.

Ko, H., Ionin, T., \& Wexler K. (2007). Parallels between L2 and L1 acquisition of article semantics. Ms. Seoul National University, University of Illinois at Urbana Champaign, and MIT.

Lyons, C. (1999). Definiteness. Cambridge: Cambridge University Press.

Master, P. (1997). The English article system: acquisition, function and pedagogy. System 25(2), 215-232.

Trenkic, D. (2002). Establishing the definiteness status of referents in dialogue (in languages with and without articles). Working papers in English and Applied Linguistics 7, 107-131. Cambridge: Research Center for English and Applied Linguistics, University of Cambridge.

Trenkic, D. (2004). Definiteness in Serbian/Croatian/Bosnian and some implications for the general structure of the nominal phrase. Lingua 114, 1401-1427.

Trenkic, D. (2007). Variability in L2 article production: beyond the representational deficit vs processing constraints debate. Second Language Research 23(3), 289-327.

Trenkic, D. (2009). Accounting for patterns of article omissions and substitutions in second language production. In Hawkins, R. \& Mayo, M. P. G. (Eds.). Second language acquisition of articles: empirical findings and theoretical implications (pp. 115-143). Amsterdam: John Benjamins. 
Pезиме

\section{СПЕЦИФИЦИРАНОСТ, ОДРЕЪЕНОСТ И УПОТРЕБА ЧЛАНОВА У ЕНГ ЛЕСКОМ ЈЕЗИКУ МЕЪУ СТУ ДЕНТСКОМ ПОПУ ЯАЦИЈОМ ИЗВОРНИХ ГОВОРНИКА СРПСКОГ ЈЕЗИКА}

Како се мали број истраживања може наћи на тему употребе чланова у енглеском језику међу популацијом изворних говорника српског језика, циљ овог дескриптивног истраживања је да се одреде основни обрасци употребе чланова у оквиру категорија одређености и специфицираности (према Ионин ет ал., 2004 интер алиа). Како би се мерила ова употреба, одређенасу четири контекста на основу следећих семантичких одлика:

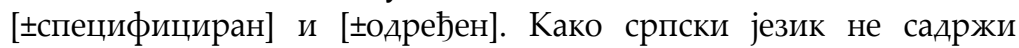
категорију чланова, и како га одликује специфицираност (Тренкиц 2002, 2004), за раздику од одређености која се кодира у енглеском језику, комбинације ових оддика требало би да одреде контексте у којима се могу пратити обрасци употребе чланова, који би могли бити основ за даља истраживања као и за процену ефекта које оваква сазнања могу имати на наставни процес. На основу резултата из претходних истраживања, већина случајева употребе погрешног члана или изостављања члана очекују се у [+одређен, специфициран] и [-одређен, +специфициран] контекстима. Садашњи резултати указују на то да се у овој популацији јавља тенденција ка прекомерној употреби одређеног члана у неодређеним контекстима, и у нешто мањој мери употреба неодређеног члана у одређеним контекстима. Такође, уочене су и неке неочекиване флуктуације у [+одређен +специфициран] анд [одређен -специфициран] контекстима, што указује на то да испитаници нису у потпуности прихватили ни одређеност ни специфицираност као одредницу за употребу чланова.

Къучне речи: специфицираност, одређеност, систем чланова енглеског језика, изворни говорници српског језика 